Ema Perme

Ministrstvo za šolstvo in šport

\title{
NACIONALNE PRIORITETE IN USPOSABLJANJE STROKOVNIH DELAVCEV ZA IZOBRAŽEVANJE ODRASLIH V SLOVENIJI
}

\section{POVZETEK}

Usposobljenost strokovnih delavcev v izobraževanju odraslih je eden od dejavnikov kakovosti, ki pripomore $k$ vključevanju $v$ vseživljenjsko učenje. Ugotavljamo rast vključevanja v neformalne programe za odrasle, pa vendar zmanjševanje vlaganj javnih financ v splošno neformalno izobraževanje odraslih glede na načrte (Analiza ReNPIO 2005-2008, 2010). Pri odraslih se, poleg primanjkljaja izobrazbe, spretnosti in poklicnih ter strokovnih kompetenc, ki je pogostejše pri nižjeizobraženih in skupinah posebne družbene skrbi (odrasli s posebnimi potrebami, drugače ranljive in marginalne skupine, Romi in različne etnične skupnosti ...), srečujemo še s situacijskimi in dispozicijskimi ovirami. Te ustvarjajo temeljne ovire za uspešno vključevanje $v$ vseživljenjsko učenje, kar pa pogosto pogojuje tudi razvoj temeljnih zmožnosti. Izobraževanje odraslih z ustrezno usposobljenimi strokovnjaki je eden od pomembnih družbenih mehanizmov za doseganje ciljev, opredeljenih v strateških dokumentih Evropske unije. ${ }^{1}$ Pred nami so velika vprašanja, saj nacionalna zakonodaja pomanjkljivo opredeljuje potrebno izobrazbo, znanje in kompetence strokovnih delavcev v izobraževanju odraslih (ZOFVI, 1996 s sprem.; ZIO, 1996 s sprem.), nekoliko doslednejša je nacionalna politika izpopolnjevanja in usposabljanja strokovnih delavcev za posebne izobraževalne programe za odrasle z javno veljavnostjo in dejavnosti izobraževanja odraslih (t. i. infrastrukturne dejavnosti: informiranje in svetovanje, samostojno učenje, kakovost ...).

Ključne besede: izobraževanje odraslih, strokovni delavci v izobraževanju odraslih, neformalno izobraževanje odraslih, programi izobraževanja odraslih, dejavnosti izobraževanja odraslih.

\section{NATIONAL PRIORITIES AND TRAINING OF ADULT EDUCATORS IN SLOVENIA - ABSTRACT}

Well-qualified educators are a vital factor for the quality of adult education, enhancing inclusion in life-long learning, An increase in interest for non-formal adult education programmes has been recorded; however, the public funds for non-formal adult education regarding future activities have been reduced (Analysis ReNPIO 2005-2008, 2010). When dealing with adults with a lack of education, skills and vocational and professional competencies, more common in people at lower educational levels and in the groups that require special social care (adults with special needs, groups that are vulnerable and marginal in other ways, the Roma and members of other ethnic communities, etc.) we tend to come across situational and dispositional obstacles. They represent the basic obstacles for successful inclusion in lifelong learning (EK, 2011), which is often a precondition for development of basic competencies. Adult education, with properly trained adult educators, is one of the key social mechanisms for reaching the goals, set in the EU strategic documents ${ }^{{ }^{*}}$. We are faced with dilemmas and challenges, since our national legislation fails to adequately determine educational requirements, knowledge and competencies for adult educators (ZOFVI, 1996; ZIO, 1996); somewhat more specific is the national policy regarding education and training of educators for special, publicly recognized programmes in adult education and specific adult education activities (infrastructural activities, provision of information and guidance, autonomous learning, quality, etc.)

Keywords: adult education, adult educators, non-formal adult education, programmes in adult education, activities in adult education.

UDK: 374.7

Kakovost usposabljanja in usposobljenosti strokovnih delavcev, ki so zaposleni v praksi izobraževanja odraslih, je ključna za kakovostno izvajanje programov in infrastrukturnih dejavnosti oziroma dejavnosti izobraževanja odraslih. ${ }^{2} \mathrm{~S}$ sistemskega vidika in po pregledu veljavne zakonodaje ugotavljamo, da sta smer in stopnja izobrazbe strokovnih delavcev opre- 
deljeni v sistemskem Zakonu o organizaciji in financiranju vzgoje in izobraževanja (Ur. 1. št. 10/1996 s sprem.; v nadaljevanju: ZOFVI) in v Zakonu o izobraževanju odraslih (Ur. 1. št. 12/1996 s sprem.; v nadaljevanju: ZIO), za dejavnosti izobraževanja odraslih pa tudi $\mathrm{v}$ dveh podzakonskih aktih: Odredbi o strokovni izobrazbi strokovnih delavcev in minimalnih standardih prostorov in opreme $\mathrm{v}$ izobraževanju odraslih (Ur. 1. št. 82/1998; v nadaljevanju: Odredba o strokovni izobrazbi in opremi) in Odredbi o standardih in normativih v izobraževanju odraslih (Ur. 1. št. 43/2000; v nadaljevanju: Odredba o standardih in normativih).

\section{POSEBNI IZOBRAŽEVALNI PROGRAMI ZA ODRASLE}

»Izobraževanje odraslih je izjemno kompleksno in heterogeno področje in obsega zelo različne izobraževalne potrebe zelo heterogene populacije ...«(Bela knjiga, 2011: 371.) »Izobraževanje odraslih po programih osnovnošolskega, poklicnega, srednjega strokovnega, gimnazijskega ter višjega strokovnega izobraževanja se ureja z zakoni, ki urejajo ta področja izobraževanja, in s tem zakonom. Izobraževanje odraslih v visokem šolstvu se ureja z zakonom, ki ureja področje visokega šolstva.« (ZIO, 1996: 1. člen.) To pomeni, da imajo odrasli možnost vključevanja v vse programe oziroma stopnje za pridobitev izobrazbe, pri čemer je v domeni zakonodaje vzgoje in izobraževanja (v nadaljevanju: VIZ) urejanje ustreznih razmerij med udeleženci in izvajalci izobraževanja odraslih ter odgovornost nacionalne politike, da skrbi za uresničevanje načel in ciljev VIZ, katerega komplementarni del je tudi izobraževanje odraslih do višješolskega izobraževanja. Poleg teh zakonodaja določa tudi »posebne izobraževalne programe za odrasle« (ZIO, 1996: 7. člen), ki so opredeljeni kot »... programi za zviševanje splošno izobraževalne in kulturne ravni prebivalstva, funkcionalno opismenjevanje, spopolnjevanje znanja za delo in poklic, za izobraževanje in usposabljanje brezposelnih, izobraževanje za demokracijo, učenje tujih jezikov, učenje slovenskega jezika za tujce, izobraževanje za kvaliteto življenja, izobraževanje za uveljavljanje posebnih pravic manjšin in odraslih s posebnimi potrebami in posebnih skupin ter drugo splošno izobraževanje odraslih « (ZIO, 1996: 7. člen). Programi, ki dosegajo opisane cilje in so namenjeni navedenim ciljnim skupinam, imajo v slovenski zakonodaji in praksi VIZ poseben položaj in status. Gre za izobraževalne programe, ki so, enako kot prej navedeni (za pridobitev izobrazbe), javnoveljavni in se zaključujejo $\mathrm{z}$ javnoveljavno listino. Sistem VIZ v Sloveniji obsega tudi vzgojne programe na ravni VIZ otrok in mladine (nacionalni kurikul za vrtce, vzgojni programi dijaških domov), ki so javnoveljavni, ne dajejo pa stopnje izobrazbe in se ne zaključujejo s prejemom javnoveljavne listine. Posebni izobraževalni programi za odrasle pomembno bogatijo izobraževanje odraslih v Sloveniji, saj zapolnjujejo vrzeli, ki so opredeljene v 7. členu ZIO, njihov položaj in razvoj lahko do določene mere opredelimo kot zrcaljenje uspešnosti VIZ otrok in mladine. Cilje, ki jim sledijo, znanja, spretnosti in kompetence, ki jih razvijajo, so na osnovnih ravneh otrok in mladine $\mathrm{v}$ VIZ zaradi narave razvoja posameznika skozi proces VIZ ter njegove morebitne primanjkljaje najpogosteje slabo prepoznani, bolje jih je mogoče prepoznati šele $\mathrm{v}$ obdobju nadaljnjega razvoja posameznika, ko ta "postane samostojen in odgovoren državljan « in se spopada $\mathrm{z}$ vsemi socialnimi vlogami (Krajnc, 1982: 47). Takrat potrebuje t. i. funkcionalna znanja za upravljanje lastnega življenja na ravni osebnih ali zasebnih potreb in razvoja kariere $\mathrm{z}$ vstopom v sfero dela. Na tem mestu je pomembno poudariti tudi, da se težave $\mathrm{z}$ enakovrednim razvojem osebnosti, nastopanjem v družbenem življenju in opravljanjem vloge aktivnega državljana ter suverenega in sa- 
mostojnega delavca, ki nastopa na trgu dela, pogosteje pojavljajo pri nižjeizobraženih in manj kvalificiranih odraslih ter $\mathrm{v}$ posebnih skupinah odraslih, ki se zaradi družbenih razmer, svojega rodu ali drugih funkcionalnih ovir težje osebno in poklicno uveljavljajo.

Slovenija se je po podatkih mednarodne raziskave o pismenosti (IALS, 1998) na štiristopenjski lestvici uvrstila precej slabo. »Rezultati raziskave na ravni celotne populacije (od 16 do 65 let) kažejo, da tri četrtine odraslih (od 65 do 77 odstotkov) v Sloveniji nima zadostnega temeljnega

Kakovostno in sistematično izobraževanje in usposabljanje strokovnih delaveev $v$ izobraževanju odraslih je ključ do dobrih rezultatov. znanja in spretnosti za ravnanje $z$ informacijami, ki jih vsebujejo različne vrste besedil, obrazci in slikovno prikazani podatki, ter za uporabo računskih operacij v vsakodnevnih okoliščinah (dosegajo 1. ali 2. raven pismenosti)« (Možina, 2001: 4). Na tej podlagi so bili pripravljeni programi opismenjevanja, ki imajo javno veljavo (pet programov Usposabljanja za življenjsko uspešnost, v zadnjih letih so bili razviti še trije, vendar za zdaj brez javne veljavnosti, in en program računalniškega opismenjevanja za odrasle $\mathrm{RPO}$, tudi $\mathrm{z}$ javno veljavo). $\mathrm{K}$ tem dodajamo še program Projektno učenje za mlajše odrasle (PUM). Za vse te sistematično pripravljamo programe usposabljanja strokovnih delavcev na nacionalni ravni. $\mathrm{V}$ tem trenutku imamo skupaj 15 različnih posebnih izobraževalnih programov za odrasle (z javno veljavnostjo), med njimi so tudi vsi javnoveljavni jezikovni programi in novorazviti program Začetna integracija priseljencev. Manj sistematike je pri strateškem načrtovanju in spremljanju gibanj strokovnih delavcev s to usposobljenostjo, prav tako nimamo posodobljenega nacionalnega ali primerjalnega spremljanja potreb odraslih, ki naj bi se v te programe vključevali. Na tej ravni je precej odgovornosti na strani tistega, ki pripravlja sistemsko in področno zakonodajo, ki je pri določbah o strokovnih delavcih v izobraževanju odraslih nedorečena in nedosledna.

\section{ZAKONSKE DOLOČBE STOPNJE IN SMERI IZOBRAZBE STROKOVNIH DELAVCEV V IZOBRAŽEVANJU ODRASLIH}

ZOFVI v 92. členu opredeljuje smer in stopnjo izobrazbe za vse strokovne delavce $\mathrm{v}$ vzgoji in izobraževanju v Sloveniji in tudi za področje izobraževanja odraslih, za katerega razvoj je pristojno ministrstvo za šolstvo in šport ( $\mathrm{v}$ nadaljevanju: MŠŠ). Področna zakonodaja izobraževanja odraslih v ZIO strokovne delavce ter njihovo stopnjo in smer izobrazbe opredeljuje na splošno, pri čemer je nekoliko podrobnejša $v$ podzakonskih aktih področne zakonodaje, vendar pa prav tam nedosledna $\mathrm{v}$ sledenju opredelitvam v ZOFVI in ZIO. Prav tako opredeljene vrste strokovnih delavcev $\mathrm{v}$ izobraževanju odraslih niso usklajene s sedanjo prakso niti z razvojnimi težnjami.

Nedoslednost v zakonodaji se kaže v konkretnih določbah, kjer npr.:

1. 92. člen ZOFVI določa stopnjo izobrazbe strokovnih delavcev vzgoje in izobraževanja, 96. in 97. člen opredeljujeta »organizatorja izobraževanja odraslih«, ki je strokovni delavec v izobraževanju odraslih;

2. pri čemer ZIO opredeljuje: »Izobraževanje odraslih opravljajo učitelji, predavatelji višjih strokovnih šol, organizatorji izobraževanja odraslih in drugi strokovni delavci.«

3. V Odredbi o strokovnih delavcih in opremi so opredelitve strokovnih delavcev oziroma njihovih vlog pri izvajanju posameznih programov in dejavnosti v podporo izobraževanju odraslih: »... vodja izobraževalnega področja, učitelji in drugi strokovni delavci v izobraževanju odraslih ...", pri čemer so ti »drugi« predstavljeni z opisom nalog kot npr. »... mentorsko in tutorsko delo lahko opravlja ...«. V isti Odredbi je »organiza- 
tor izobraževanja odraslih « naveden šele v 5. členu in predstavljen kot možna analogija z vodjo izobraževalnega področja.

4. V Odredbi o standardih in normativih pa je $\mathrm{v}$ določbah dikcija »... andragoški in drugi strokovni delavci - organizatorji izobraževanja odraslih ...« pri posameznih t. i. infrastrukturnih dejavnostih oziroma dejavnostih izobraževanja odraslih.

Prav tako je zakonodaja, enako kot pri opredelitvah vlog, nedosledna pri določbah predpisane minimalne stopnje izobrazbe:

1. Določbe v ZIO določajo »visoko stopnjo izobrazbe « za vse strokovne delavce v VIZ.

2. V ZIO, kjer »... učitelji, predavatelji višjih strokovnih šol, organizatorji izobraževanja odraslih in drugi strokovni delavci ...« izpolnjujejo »pogoje za strokovne delavce ...«, $\mathrm{ki} \gg . .$. se urejajo $v$ skladu z zakonom, ki ureja organizacijo vzgoje in izobraževanja, če s tem zakonom ni drugače določeno ... «. In ker ZIO v nadaljevanju določa »smer visokošolske izobrazbe ... «, ${ }^{3}$ to pomeni, da sledi določbam sistemskega zakona.

3. Žal se nedoslednost pojavi v podzakonskem aktu področne zakonodaje izobraževanja odraslih - Odredbi o standardih in normativih, saj ta določa, da se »obračunajo sredstva za enega strokovnega delavca z višjo strokovno izobrazbo«.

4. Zakonodaja jasno opredeljuje smer in stopnjo izobrazbe za vse, ki izvajajo javnoveljavne programe za pridobitev izobrazbe, zatakne pa se pri določbah opredelitve dodatnih usposobljenosti izvajalcev posebnih izobraževalnih programov za odrasle, ki so javnoveljavni (in ne dajejo stopnje izobrazbe). Določba smeri in stopnje izobrazbe strokovnih delavcev za te programe, kot smo ugotovili zgoraj, ni dovolj, ZOFVI ali ZIO pa ne določata, da je poleg smeri in stopnje izobrazbe treba določiti tudi dodatna znanja oziroma usposobljenosti vseh, ki izvajajo posebne izobraževalne programe za odrasle.

\section{STROKOVNA PRIPRAVLJENOST ZA IZOBRAŽEVANJE ODRASLIH}

Študijski programi področja andragogike za izobraževanje strokovnjakov, ki se zaposlujejo v izobraževanju odraslih, ustrezajo določbam zakonodaje ter zagotavljajo trdno in ustrezno teoretsko in splošno raven, ${ }^{4}$ vendar pa področna zakonodaja ne predpisuje zaposlovanja strokovnjakov s področja andragoških, pedagoških, psiholoških ved in drugih sorodnih humanističnih ter družboslovnih smeri za posamezna področja dela v izobraževanju odraslih, kot je to mogoče zaslediti v formalnem izobraževanju, npr. v osnovnošolskem izobraževanju otrok, kjer je določeno, da slovenskega jezika ne more poučevati učitelj angleškega jezika (op. a.: namenoma navajam preprost primer). Splošna humanistična izobrazba in dobro teoretsko poznavanje področja izobraževanja odraslih je za prakso nujna osnova in dobro izhodišče za izobraževalno delo. Za specifična področja dela in naloge $\mathrm{v}$ izobraževanju odraslih pa je na tej podlagi znanje nujno nadgrajevati in dopolnjevati. Prav nedoslednost področne zakonodaje pri opredeljevanju strokovnih delavcev in njihove predhodne izobrazbe ima lahko najmanj dve posledici (op. a.: dihotomijo sem uporabila namenoma):

- pozitivno, saj so zaradi nje $\mathrm{v}$ izobraževanju odraslih zaposleni tudi drugi strokovnjaki, ki so si bodisi pridobili osnovno pedagoško-anadragoško izobrazbo (izvajajo izobraževalno dejavnost $\mathrm{v}$ formalnih programih) bodisi da delujejo kot vodje, organizatorji, informatorji, svetovalci $\mathrm{v}$ dejavnostih izobraževanja odraslih ali kot izvajalci različnih neformalnih programov za odrasle brez javne veljavnosti in so $\mathrm{v}$ prakso izobraževanja odraslih vnesli širino vseživljenjskosti učenja;

- negativno, saj zaradi nje na področju izobraževanja odraslih in določbah smeri in stopnje izobrazbe, specialnih znanj in usposobljenosti strokovnih delavcev za izvajanje posebnih izobraževalnih programov za odrasle, splošnih neformalnih programov 
(brez javne veljave, financiranih iz javnih sredstev) in dejavnosti izobraževanja odraslih, za katere so oblikovane strokovne mreže, razmeroma enakomerno razširjene po državi, ni jasnih zakonskih določb, nasprotno, področni podzakonski akti celo »spreminjajo « določila ZOFVI in ZIO o predpisani stopnji izobrazbe.

Strokovnjaki, ki prihajajo v izobraževanje odraslih, za delo v neformalnih programih nimajo predpisane smeri izobrazbe, prav tako nimajo predpisane zahteve o pridobitvi temeljne pedagoško-andragoške izobrazbe. To poleg specialnih zahtev po znanju v posebnih izobraževalnih programih za odrasle še povečuje potrebo po oblikovanju programov za usposabljanje strokovnih delavcev $v$ izobraževanju odraslih za namene izvajanja nekaterih dejavnosti izobraževanja odraslih, kar bi zagotavljo dobro izhodišče za kakovostno izvajanje programov in dejavnosti izobraževanja odraslih v Sloveniji in za vzpostavljanje t. i. strokovne mreže in koordinacije.

$\mathrm{Na}$ nacionalni ravni je vzpostavljen razmeroma jasen mehanizem, kdo in kdaj lahko pridobi dodatna znanja in $\mathrm{s}$ tem tudi izpolni pogoje za izvajanje posebnih izobraževalnih programov in dejavnosti izobraževanja odraslih. S sistemskim urejanjem strokovnih znanj izvajalcev pa bi se v prihodnje lahko izognili:

- razmeroma veliki fluktuaciji strokovnih delavcev;

- slabi preglednosti razpoložljivih in usposobljenih strokovnih delavcev;

- neenakomerni oziroma slabo pregledni razporeditvi izvajalcev, strokovnih delavcev in programov ter dejavnosti $\mathrm{v}$ podporo v izobraževanju odraslih v državi;

- slabemu nacionalnemu načrtovanju oziroma projekciji potreb in strategije razvoja usposabljanj strokovnih delavcev v izobraževanju odraslih.

Ob vsem tem je pomanjkljiva tudi metodologija spremljanja izvajanja dodatnih usposabljanj strokovnih delavcev za posebne izobraževal- ne programe in dejavnosti izobraževanja odraslih, saj iz obstoječih podatkov ni mogoče zagotoviti jasnega pregleda:

- števila strokovnih delavcev, ki so končali več usposabljanj za izvajanje posameznih posebnih izobraževalnih programov oziroma dejavnosti izobraževanja odraslih;

- števila usposobljenih in še dejavnih strokovnih delavcev;

- primanjkljaja strokovnih delavcev;

- razporeditve izvajalcev $\mathrm{z}$ usposobljenimi strokovnimi delavci za posamezne programe in dejavnosti po državi;

- porabljenih nacionalnih sredstev in sredstev Evropskega socialnega sklada (v nadaljevanju: ESS) za usposabljanje strokovnih delavcev;

- porabe sredstev za nadaljnje usposabljanje strokovnih delavcev v izobraževanju odraslih za programe in dejavnosti, ki sodijo $\mathrm{v}$ nacionalne prioritete;

- višje stopnje kakovosti usposabljanj in dodatnih usposabljanj ter izvajanja programov in dejavnosti izobraževanja odraslih.

\section{DODATNA USPOSABLJANJA ZA POSEBNE IZOBRAŽEVALNE PROGRAME IN DEIAVNOSTI IZOBRAŽEVANIA ODRASLIH}

V prejšnjem poglavju omenjene podatke, analize in metodologijo $\mathrm{v}$ slovenskem sistemu urejanja politike izobraževanja odraslih nujno potrebujemo. Prvotna namera te predstavitve je bil prikaz števila vključenih strokovnih delavcev in vloženih finančnih sredstev $\mathrm{v}$ obdobju 2000-2011. Vsa tovrstna usposabljanja strokovnih delavcev na nacionalni ravni so bila po letu 2005 umeščena $\mathrm{v}$ mehanizem financiranja iz sredstev ESS in nacionalnega deleža MŠŠ znotraj Operativnega programa kohezijske politike in razvoja človeških virov. To je povzročilo nemalo administrativnih ovir in posledično tudi nihanja $\mathrm{v}$ vlaganju finančnih sredstev in v udeležbi. 
Prav zaradi vseh naštetih pomanjkljivosti je mogoč le prikaz števila udeležb oziroma vključitev (op. a.: to ni število strokovnih delavcev) v programe usposabljanja za izvajanje posebnih izobraževalnih (javnoveljavnih programov) za odrasle za področje opismenjevanja in PUM ter izvajanje dejavnosti izobraževanja odraslih (svetovanje, kakovost, samostojno učenje, borza znanja, študijski krožki). Tudi natančnih finančnih sredstev ni bilo mogoče izluščiti, saj so bila financiranja teh programov za strokovne delavce »utopljena « v širših projektih.

Opazna sta velika rast udeležb v letu 2006 na račun sredstev ESS in močan padec $v$ letu 2008, ko se je končala t. i. stara finančna perspektiva (2004-2006), ni pa še bil povsem vzpostavljen tok aktivnosti t. i. druge finančne perspektive (2007-2013).

Programi opismenjevanja so nacionalna prioriteta, zato je spremljanje strokovnih delavcev in njihovo usposabljanje še toliko pomembneje.

\section{IZOBRAŽEVANJE ODRASLIH V PRAKSI: PROGRAM, DEJAVNOSTI IN IZVAJALCI}

Razvoj izobraževanja odraslih v Sloveniji je $\mathrm{v}$ 90. letih temeljil na rezultatih raziskav in analiz in je začrtal niz t. i. infrastrukturnih dejavnosti izobraževanja odraslih tudi v sami praksi, ne le $\mathrm{v}$ razvoju na nacionalni ravni. Novooblikovani modeli, ki so v začetku delovali v obliki projektnih in pilotnih načinov za spodbujanje vključevanja $v$ učenje in izobraževanje odraslih (središča za samostojno učenje, borza znanja, študijski krožki, spodbujanje uresničevanja vseživljenjskega učenja), so se v slovenskem prostoru razmeroma dobro uveljavili in gotovo opravljajo svojo funkcijo uresničevanja koncepta vseživljenjskega učenja. To dokazujejo tudi podatki vključevanja ljudi v te dejavnosti. Od leta 2005 pa v Sloveniji nastaja nov model partnerskega povezovanja na območju posameznih statističnih regij, katerega
Slika 1: Število udeležb v programih usposabljanja strokovnih delavcev v letih 2000-2011 za izvajanje posebnih izobraževalnih programov in dejavnosti izobraževanja odraslih

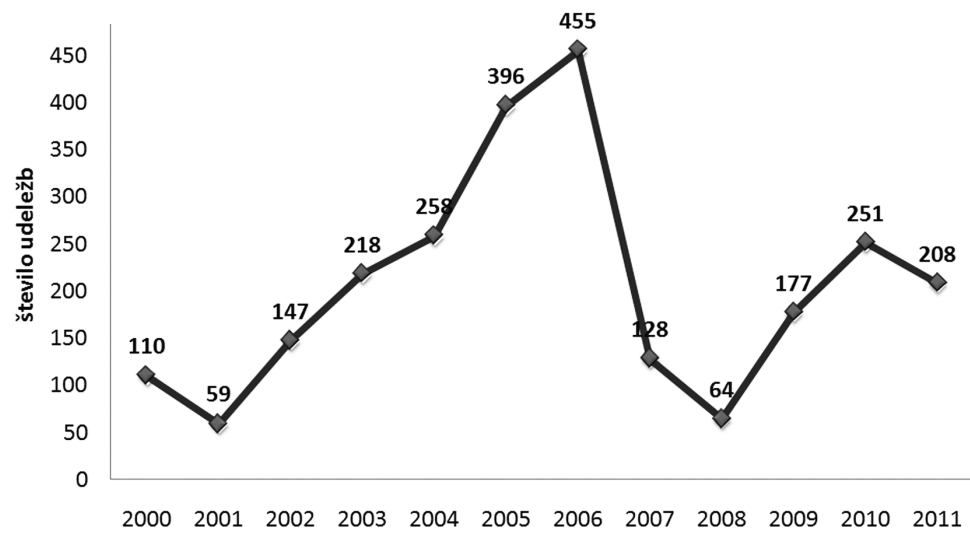

Slika 2: Število vključitev strokovnih delavcev v usposabljanje za izvajanje posameznih posebnih izobraževalnih programov in dejavnosti izobraževanja odraslih v posameznih letih za obdobje 2000-2011 (rast in padanje kažeta na razpoložliivost sredstev)

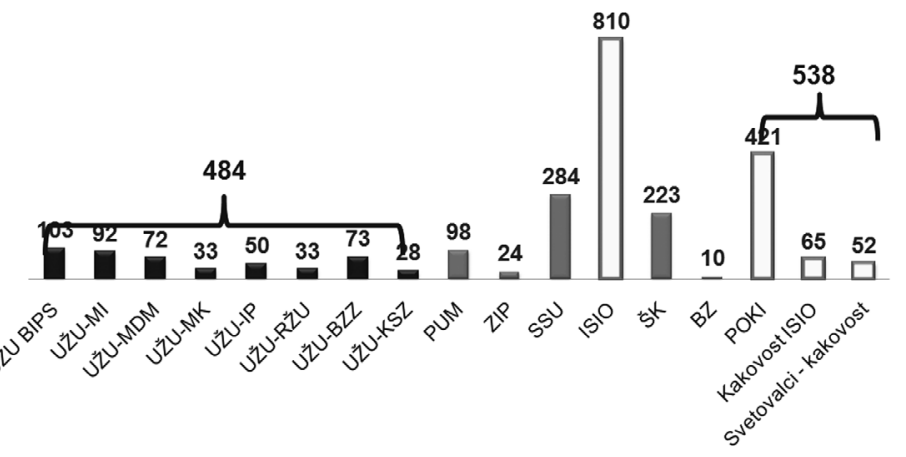

Slika 3: Gostota programov usposabljanja v posameznih letih in število vključitev v programe usposabljanja za izvajanje programov Usposabljanja za življenjsko uspešnost (UŽU) v obdobju 2000-2011

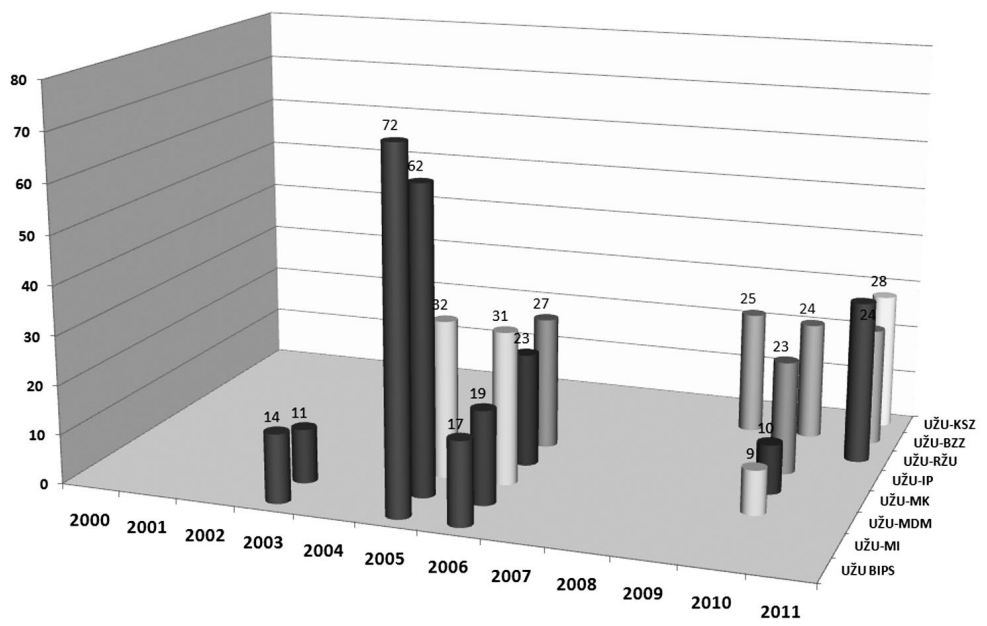


cilj je skupno ugotavljanje potreb in načrtovanje različnih dejavnosti na področju izobraževanja odraslih, kot so informiranje, svetovanje, učenje, izobraževanje ... Usmeritev je zasnovana na nacionalni ravni in se v celoti financira iz sredstev ESS in MŠŠ. V t. i. centrih vseživljenjskega učenja (v nadaljevanju: CVŽU) sodelujejo različni akterji iz lokalnega okolja: nosilna inštitucija je javni zavod za izobraževanje odraslih, kot partnerji pa sodelujejo tudi druge izobraževalne in kulturne organizacije javnega ali zasebnega prava, podjetja, interesna združenja ipd.

V Sloveniji imamo vzpostavljene tudi t. i. strokovne mreže ali koordinacije dejavnosti izobraževanja odraslih, ki jih $\mathrm{v}$ celoti ali delno financiramo iz javnih sredstev: organizirano samostojno učenje (33 središč za samostojno učenje - v nadaljevanju: SSU), 14 informacijsko-svetovalnih središč za izobraževanje odraslih (v nadaljevanju: ISIO) s 124 »dislokacijami« v okviru centrov vseživljenjskega učenja (v nadaljevanju: CVŽU), vsako leto okrog 280 študijskih krožkov, eno osrednjo in štiri regijske borze znanja, 14 CVŽU s 53 točkami zunaj matične lokacije, okrog pet tisoč dejavnosti in prireditev

Slika 4: Vrste izvajalcev izobraževanja odraslih glede na pravnoorganizacijsko obliko s pretežno usmerjenostjo $v$ izvajanje formalnih in neformalnih programov ter dejavnosti v izobraževanju odraslih

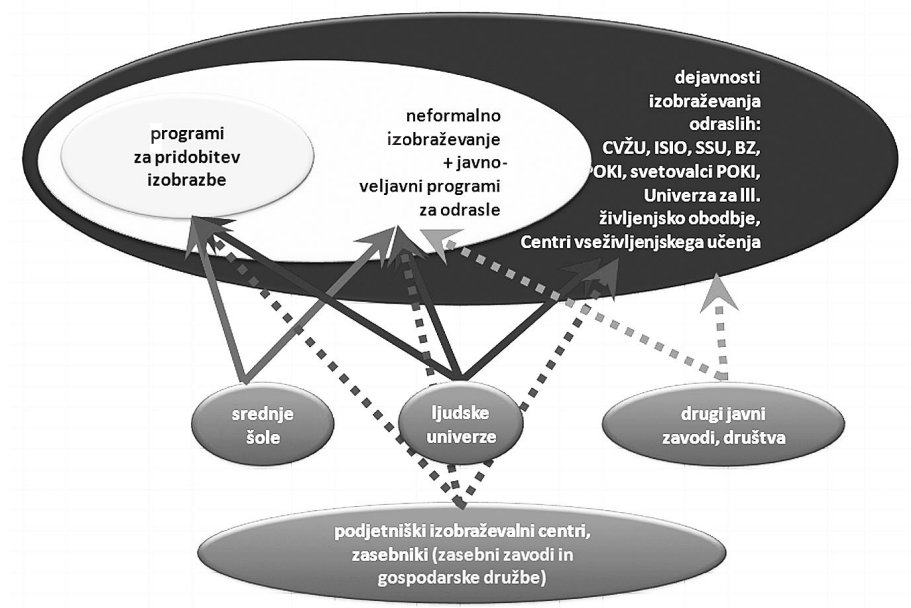

ob tednu vseživljenjskega učenja, 45 društev Univerze za tretje življenjsko obdobje.

$\mathrm{Na}$ nacionalni ravni za razvoj $\mathrm{v}$ praksi skrbi osrednja razvojna in raziskovalna inštitucija Andragoški center Slovenije, ki ima ob večinskem financiranju MŠŠ posebej opredeljene naloge tudi s sredstvi ministrstva za delo, družino in socialne zadeve ( $v$ nadaljevanju: MDDZS). Ta z vključevanjem v mednarodne projekte in pridobivanjem dodatnih virov na tej ravni razvija programe usposabljanja za strokovne delavce $\mathrm{v}$ izobraževanju odraslih in jih tudi izvaja, izdaja različne strokovne publikacije, skrbi za strokovno informiranje in svetovanje, razvija in uvaja visoke standarde kakovosti $\mathrm{v}$ izobraževanje odraslih v Sloveniji.

Posledica heterogenih programov in dejavnosti v podporo izobraževanju odraslih je tudi heterogena mreža izvajalcev glede na vrsto programov (formalni programi, posebni izobraževalni programi, splošni neformalni programi) in dejavnosti izobraževanja odraslih. Za izvajanje formalnih programov izobraževanja odraslih po podatkih v letu 2011 skrbi: 93 srednjih šol, 61 zasebnikov ali specializiranih organizacij za izobraževanje odraslih (opredelitev po ZIO; vključeni zasebni zavodi in gospodarske družbe), 31 ljudskih univerz, 28 javnih in 23 zasebnih višjih šol. Programe UŽU, RPO in PUM v obdobju 2010-2013 izvaja 80 izvajalcev, izbranih po razpisu za sredstva ESS in deleža MŠŠ, z različno pravnoorganizacijsko obliko (javni zavodi za izobraževanje odraslih - ljudske univerze, drugi javni zavodi, zasebni zavodi, zasebne organizacije, specializirane za izobraževanje odraslih, društva, razvojne agencije). Programe splošnega neformalnega izobraževanja odraslih (financirane po sprejetju letnega programa izobraževanja odraslih iz nacionalnega proračuna MŠŠ za vsako leto posebej) izvajajo poleg prej naštetih tudi druge gospodarske družbe, ne le zasebne organizacije za izobraževanje odraslih, različna interesna združenja in društva, tudi sindikati. 


\section{NACIONALNE USMERITVE PRO- GRAMOV IN USPOSABLJANIA STROKOVNIH DELAVCEV}

Razvoj in izvajanje dodatnih krajših in usmerjenih programov usposabljanja strokovnih delavcev, ki jih pripravljamo na nacionalni ravni in vanje tudi razmeroma sistematično vlagamo, je nujna naloga. Skladno s strateškimi dokumenti na področju izobraževanja odraslih na nacionalni ravni je za izobraževanje strokovnih delavcev pristojno MŠŠ ${ }^{5}$ Usmerjanje politike MŠS vsekakor posega v najvišjo raven dodatnega usposabljanja strokovnih delavcev izobraževanja odraslih, ki jo dosegamo v državi, postavlja pa se vprašanje, ali to zadošča z vidika primanjkljajev in potreb, da bi ustrezno zapolnili vrzeli, ki po:

- eni strani nastajajo kot posledica ohlapnih določb zakonodaje in $\mathrm{v}$ nadaljevanju s kadrovanjem strokovnjakov iz drugih strok, ki vstopajo v izobraževanje odraslih brez temeljnih pedagoško-andragoških znanj in teoretskih osnov na področju izobraževanja odraslih;

- po drugi strani pa potrebe po dodatnem usposabljanju strokovnih delavcev nastajajo tudi zaradi nuje po dodatnih, specialnih znanjih za posebne izobraževalne programe za odrasle in izvajanje dejavnosti izobraževanja odraslih.

Na področju programov opismenjevanja za zdaj ostajamo pri več kot desetletje starih mednarodno primerljivih raziskovalnih ugotovitvah, pri čemer so bile v letu 2010 na nacionalni ravni opravljene tri študije s ciljem temeljite evalvacije programov opismenjevanja in programa PUM (ACS, 2010), na podlagi katerih so nastala Strokovna izhodišča za prenovo javnoveljavnih programov UŽU, PUM in RPO ter temeljnega usposabljanja učiteljev in mentorjev (ACS, 2011). Gre za dragocen prispevek za prakso izvajanja teh programov in posebej za nadaljnje načrtovanje razvoja in implementacije usposabljanja strokovnih delavcev (učiteljev, mentorjev ...).

Krovni strateški dokument, ki je določen z ZIO, je nacionalni program za izobraževanje odraslih, ki ga sprejema državni zbor in ki opredeljuje: »... cilje izobraževanja odraslih, prednostna področja izobraževanja odraslih, dejavnosti, potrebne za izvajanje izobraževanja odraslih in določi globalni obseg javnih sredstev « (ZIO, 1996: 22. in 23. člen). Tako so bile za prvo resolucijo o nacionalnem programu izobraževanja odraslih (v nadaljevanju: ReNPIO) ${ }^{6}$ za obdobje 2005-2010 v letu 2004 oblikovane nacionalne prioritete: 1. splošno izobraževanje in učenje odraslih; 1l. izobraževanje za dvigovanje izobrazbene ravni; 11l. izobraževanje in usposabljanje za potrebe trga dela ter dejavnosti, potrebne za izvajanje izobraževanja, ki podpirajo vsa tri prednostna področja. ReNPIO je strateški dokument in opredeljuje smer razvoja, hkrati daje podlago za operativni dokument, tj. letni program izobraževanja odraslih, ki ga vsako leto sprejema vlada. Obdobje prve resolucije se je končalo leta 2010 in analiza je pokazala realizacijo in doseganje kazalnikov glede na zastavljene cilje za celotno obdobje resolucije.

Slika 5: Načrtovana sredstva in realizacija glede na letni program v posameznem letu uresničevanja ReNPIO, prikazano za obdobje 2007-2010 (struktura financiranja po prednostnih področjih in dejavnostih izobraževanja odraslih)

\begin{tabular}{|c|c|c|c|c|c|c|c|c|c|c|c|c|c|c|c|c|}
\hline Prednostno področje & $\begin{array}{c}\text { ReNPIO } \\
2007 \\
\text { v EUR }\end{array}$ & $\begin{array}{c}\text { Delež } \\
\text { v \% }\end{array}$ & $\begin{array}{l}\text { LPIO } \\
2007 \\
\text { V EUR }\end{array}$ & $\begin{array}{c}\text { Delež } \\
\text { v \% }\end{array}$ & $\begin{array}{c}\text { ReNPIO } \\
2008 \\
\text { v EUR }\end{array}$ & $\begin{array}{c}\text { Delež } \\
\text { v \% }\end{array}$ & $\begin{array}{l}\text { LPIO } \\
2008 \\
\text { V EUR }\end{array}$ & $\begin{array}{c}\text { Delež } \\
\text { v \% }\end{array}$ & $\begin{array}{c}\text { ReNPIO } \\
2009 \\
\text { v EUR }\end{array}$ & $\begin{array}{c}\text { Delež } \\
\text { v \% }\end{array}$ & $\begin{array}{l}\text { LPIO } \\
2009 \\
\text { V EUR }\end{array}$ & $\begin{array}{c}\text { Delež } \\
\mathbf{v} \%\end{array}$ & $\begin{array}{c}\text { ReNPIO } \\
2010 \\
\text { v EUR }\end{array}$ & $\begin{array}{l}\text { De- } \\
\text { lež } \\
\mathbf{v} \%\end{array}$ & $\begin{array}{l}\text { LPIO } \\
2010 \\
\text { V EUR }\end{array}$ & $\begin{array}{c}\text { Delež } \\
\text { v \% }\end{array}$ \\
\hline I. & $10,462,360$ & 27 & $9,602,713$ & 18 & $11,617,426$ & 25,7 & $5,881,301$ & 16,3 & $12,223,335$ & 24,7 & $8,495,229$ & 20,2 & $12,875,981$ & 24 & $13,201,210$ & 23,3 \\
\hline II. & $15,063,846$ & 38,9 & $21,009,680$ & 39,5 & $17,280,921$ & 38,2 & $10,308,411$ & 28,6 & $18,889,584$ & 38,2 & $10,090,072$ & 23,9 & $20,729,427$ & 38 & $9,605,575$ & 17 \\
\hline III. & $6,985,478$ & 18 & $17,502,207$ & 32,9 & $9,004,340$ & 19,9 & $13,540,351$ & 37,6 & $10,371,808$ & 20,9 & $17,111,749$ & 40,6 & $11,810,633$ & 22 & $27,043,179$ & 47,8 \\
\hline $\begin{array}{l}\text { Infrastruktura } \\
\text { / dejavnosti }\end{array}$ & $, 228,927$ & 16,1 & $5,112,301$ & 9,6 & $7,307,211$ & 16,2 & $6,262,451$ & 17,4 & $8,023,702$ & 16,2 & $6,455,595$ & 15,3 & $8,809,881$ & 16 & $6,735,021$ & 11,9 \\
\hline SKUPAJ & $38,740,611$ & 100 & $53,226,701$ & 100 & $45,209,898$ & 100 & $35,992,514$ & 100 & $49,508,429$ & 100 & $42,152,645$ & 100 & $54,225,922$ & 100 & $56,584,985$ & 100 \\
\hline
\end{tabular}




\section{USMERITVE V EVROPSKIH} STRATEŠKIH DOKUMENTIH

Akcijski načrt za izobraževanje odraslih Za učenje je vedno pravi čas 2007-2010 (EK, 2007) je med svojimi akcijskimi cilji znotraj poglavja Izboljšanje kakovosti na področju izobraževanja odraslih opredeljeval tudi »razvoj standardov za strokovnjake na področju izobraževanja odraslih, vključno z usmerjanjem, ki temelji na obstoječih dobrih praksah« (EK, 2007: 8), kar v celoti sovpada $\mathrm{z}$ nacionalnimi usmeritvami in strategijami na tej ravni. Evropski dokument kot tak in aktivnosti, ki so se izvajale na njegovi podlagi, ter poročilo, ki je nastalo s pregledom analiz posameznih držav članic in med članicami, pa pomenijo dobro referenčno točko za Slovenijo. Usmerjanje dodatnega izobraževanja strokovnih delavcev $\mathrm{v}$ izobraževanju odraslih v Sloveniji je med državami članicami ocenjeno kot dobro, saj v večini držav nimajo tako usmerjenega izvajanja tovrstnega izobraževanja. V prihodnje se države članice usmerjajo po novonastalih dokumentih, pri čemer je Izobraževanje in usposabljanje 2020 (ET, 2010) s poudarkom na »izboljšanju kakovosti in učinkovitosti izobraževanja in usposabljanja« vplival tudi na novo resolucijo sveta o prenovljeni evropski agendi za izobraževanje odraslih $2012-2014,{ }^{7} \mathrm{ki}$ opredeljuje naslednja prednostna področja: 1 . zagotavljanje vseživljenjskega učenja in mobilnosti; 2. izboljšanje kakovosti in učinkovitosti izobraževanja in usposabljanja; 3 . spodbujanje pravičnosti, socialne kohezije in aktivnega državljanstva skozi izobraževanje odraslih; 4. krepitev ustvarjalnosti in inovativnosti odraslih in njihovo učno okolje; 5 . izboljšanje temeljnega poznavanja in spremljanje sektorja izobraževanja odraslih.

\section{NAMESTO ZAKLJUČKA}

Kakovostno in sistematično izobraževanje in usposabljanje strokovnih delavcev v izobraževanju odraslih je vsekakor ključ do kakovosti in dobrih rezultatov na področju vključevanja v učenje in izobraževanje odraslih na vseh ravneh in $v$ vse oblike in vrste. To se kaže skozi različne aktivnosti in vloge, v katerih se pojavljajo odrasli, od osebnih do poklicnih. Prepoznani primanjkljaji v zakonodaji in pomanjkljivi mehanizmi spremljanja gibanj usposobljenih strokovnih delavcev, posebej za programe, ki jih uvrščamo med t. i. nacionalne prioritetne programe, so gotovo pomemben podatek za nadaljnje načrte in ukrepe, ki jih bo treba v prihodnje urediti na sistemski ravni, seveda poleg drugih spremljajočih nalog.

\section{LITERATURA}

Action Plan on Adult learning - It is always a good time to learn (2007). Brussel: Commission of the european communities. Dostopno na: http:// ec.europa.eu/education/policies/adult/com558_ en.pdf (7. 11. 2011).

Analiza uresničevanja Resolucije o nacionalnem programu izobraževanja odraslih do 2010 v obdobju 2005-2008. (2010). Ljubljana: Andragoški center Slovenije. Dostopno na: http://arhiv.acs.si/porocila/Analiza_ReNPIO.pdf (7. 11. 2011).

Bela knjiga o vzgoji in izobraževanju v Republiki Sloveniji 2011. (2011). Ljubljana: Zavod RS za šolstvo. Dostopno na: http://www.belaknjiga2011. si/pdf/bela_knjiga_2011.pdf (7. 11. 2011).

Brenk, E. (2011). Pregled ponudbe izobraževanja odraslih v Sloveniji v letih 2010/2011. Poročila in analize. Dostopno na: http://arhiv.acs.si/dokumenti/Evalvacija_JVP-UZU_in_TU_UZU.pdf (7. 11. 2011).

Broek, S. D.; Buiskool, B. J.; Hake, B. (2010). Impact of ongoing reforms in education and training on the adult learning sector: Final Report. Dostopno na: http://adultlearning-budapest2011.teamwork.fr/docs/Ongoing-Reforms-Adult-Learning-Final-Report.pdf (21. 7. 2011).

Council Conclusions on a strategic framework for European cooperation in education and training (»ET 2020«). (2009). Bruselj: The council of the European Union. Dostopno na: http://konferencje. frse.org.pl/img/Mfile/357/file.pdf (21. 11. 2011).

Draft Council Resolution on a renewed European agenda for adult learning Adoption of a Council Resolution. (2011). Bruselj: Education Committee.

Drofenik, O. (1999). Nacionalni program izobraževanja odraslih. Cilji, dejavnosti, utemeljitve. 2. zv. Ljubljana: Andragoški center Slovenije. 
Evalvacija javno veljavnega Programa za mlajše odrasle (PUM) in temeljnega usposabljanja mentorjev (TUM). (2010). Ljubljana: Andragoški center Slovenije. Dostopno na: http://arhiv.acs.si/dokumenti/ Evalvacija_JVP-PUM_TUM_PUM.pdf (7. 11. 2011).

Evalvacija javno veljavnega programa Usposabljanja za življenjsko uspešnost (UŽU) in temeljnega usposabljanja za učitelje v programu UŽU. (2010). Ljubljana: Andragoški center Slovenije. Dostopno na: http://arhiv.acs.si/dokumenti/Evalvacija_JVP-UZU_in_TU_UZU.pdf (7. 11. 2011).

Europe 2020 - A European strategy for smart, sustainable and inclusive growth. (2010). Bruselj: European Commission. Dostopno na: http://europa.eu/ press_room/pdf/complet_en_barroso__007_-_europe_2020_-_en_version.pdf (21. 11. 2011).

Ivančič, A.; Svetina, M. (2008). »Vseživljenjsko učenje, preverjanje in vrednotenje ter prenos znanja«. V: Podmenik (ur.), Sociokulturni in organizacijski vidiki prenosa znanja. Ljubljana.

Jelenc Krašovec, S.; Kump, S. (2009), »Sistemsko urejanje izobraževanja odraslih «. Sodobna pedagogika, 60, 1: 198-216.

Jelenc, Z. (ur.) (2007). Strategija vseživljenjskosti učenja v Sloveniji. Ljubljana: Ministrstvo za šolstvo in šport in Pedagoški inštitut.

Kirsch, I. (2001). The International Adult Literacy Survey (IALS): Understanding What Was Measured. New York: Statistics \& Research Division. Dostopno na: http://www.ets.org/Media/Research/ pdf/RR-01-25-Kirsch.pdf (21. 11. 2011).

Klemenčič, S., Možina, T., Žalec, N. (2009). Kompetenčni pristop $k$ spopolnjevanju andragoških delavcev. Ljubljana: Andragoški center Slovenije.

Krajnc, Ana (1982). Motivacija za izobraževanje. Ljubljana: Delavska enotnost.

Mohorčič Špolar, V.: Mirčeva, J.; Ivančič, A.; Radovan, M. (2006). Družbenoskupinski vplivi udeležbe odraslih v izobraževanju kot podlaga za razvoj modela poklicne kariere. Ljubljana: Andragoški center Slovenije. Dostopno na: http://porocila.acs. si/datoteke/Model\%20poklicne\%20kariere\%20_ koncni\%20txt_.pdf (7. 11. 2011).

Mohorčič Špolar, V.: Mirčeva, J.; Ivančič, A.; Možina E.; Radovan, M. (2005). Pismenost in ključne življenjske veščine v družbi znanja: družbenoskupinski vplivi udeležbe odraslih v izobraževanju kot dejavnik razvoja družbe znanja. Ljubljana: Andragoški center Slovenije. Dostopno na: http://porocila.acs.si/datoteke/naslovnica.pdf (7. 11. 2011).
Možina, E. (2001). Pismenost in udeležba odraslih v izobraževanju - predstavitev raziskave (povzetek iz neobjavljenega nacionalnega poročila o pismenosti odraslih v Sloveniji). Predstavljeno na Seminarju šolskega polja, CEPS, 21. februar 2001. Dostopno na: http://www.see-educoop.net/ education_in/pdf/pismenost_odrasli-slo-svn-t07. pdf (7. 11. 2011).

Možina, T.; Klemenčič, S. (2008). Razvoj kakovosti izobraževanja odraslih, notranje in zunanje presojanje kakovosti. Ljubljana: Andragoški center Slovenije.

Nadaljnje izobraževanje, Slovenija, 2008/2009 končni podatki, SURS. Dostopno na: http://www. stat.si/novica_prikazi.aspx?id=3233 (7. 11. 2011).

Nadaljnje izobraževanje, Slovenija, 2009/10 - končni podatki, SURS. Dostopno na: http://www.stat.si/ novica_prikazi.aspx?id=4044 (7. 11. 2011).

Odredba o standardih in normativih $v$ izobraževanju odraslih. Ur. 1. RS št. 43/2000. Dostopno na: http://www.uradni-list.si/1/objava. jsp?urlid=200043\&stevilka=1991 (21. 11. 2011).

Odredba o strokovni izobrazbi strokovnih delavcev in minimalnih standardih prostorov in opreme v izobraževanju odraslih. Ur. 1. RS št. 82/1998. Dostopno na: http://www.uradni-list.si/1/objava. jsp?urlid=199882\&stevilka=4184 (21. 11. 2011).

Perme, E. (ur.) (2008). Zveza ljudskih univerz Slovenije predstavlja svoje članice. Ljubljana: Zveza ljudskih univerz.

Prikaz dosežkov in razvojnih izzivov izobraževalne dejavnosti Andragoškega centra Slovenije. Izhodišča za oblikovanje nove zasnove andragoškega spopolnjevanja. (2008). Ljubljana: ACS. Dostopno na: http://arhiv.acs.si/porocila/Prikaz_dosezkov_in_razvojnih_izzivov_izobrazevalne_dejavnosti_ASC.pdf (7. 11. 2011).

Prikaz dosežkov in razvojnih izzivov izobraževalne dejavnosti Andragoškega centra Slovenije. Izhodišča za oblikovanje nove zasnove andragoškega izpopolnjevanja. (2008). Ljubljana: Andragoški center Slovenije.

Resolucija o nacionalnem programu izobraževanja odraslih v Republiki Sloveniji do leta 2010 (ReNPIO). (2004). Ur. 1. RS št. 70/04. Dostopno na: http://www.uradni-list.si/1/objava. jsp?urlid=200470\&stevilka=3149 (21. 11. 2011).

Strokovna izhodišča za prenovo javno veljavnih programov UŽU, PUM in RPO ter temeljnega usposabljanja učiteljev in mentorjev. (2011). Ljubljana: 
Andragoški center Slovenije. Dostopno na: http:// arhiv.acs.si/dokumenti/Strokovna_izhodisca_za_ prenovo_JVP_UZU_PUM_RPO_ter_TU_uciteljev_in_mentorjev.pdf (7. 11. 2011).

Zakon o izobraževanju odraslih (ZIO-UPB1). Ur. 1. RS št. 110/06. Dostopno na: http://www.uradni-list.si/1/objava.jsp?urlid=2006110\&stevilka=4673 (21. 11. 2011).

Zakon o organizaciji in financiranju vzgoje (ZOFVI-UPB5). Ur. 1. RS št. 16/07. Dostopno na: http://www.uradni-list.si/1/objava. jsp?urlid=200716\&stevilka=718 (21. 11. 2011).

1 Europe 2020; Education and training 2020.

2 Področna zakonodaja izobraževanja odraslih (Zakon o izobraževanju odraslih; Ur. l. št. 12/96 s sprem.) nekoliko nedosledno opredeljuje infrastrukturne dejavnosti v izobraževaju odraslih. Termin "infrastruktura« $v$ vzgoji in izobraževaju je razumljen zoženo, kot tehnična podpora vzgojni in izobraževalni dejavnosti, in v kontekstu izobraževanja odraslih ne odraža vsebine, kot je informiranje, svetovanje, organizirano samostojno učenje, promocija, razvoj, raziskave, publicistika, kakovost, tako na nacionalni ravni kot v praksi izobraževanja odraslih v konkretni obliki dejavnosti, ki smo jih v Sloveniji razvili od osamosvojitve in prinašajo različne oblike motivacije za vseživljenjsko učenje odraslih, relativno enakomerno razmeščene po državi kot strokovne mreže (svetovalna dejavnost, organizirano samostojno učenje, mreža študijskih krožkov, borze znanja, svetovanje za kakovost, tudi dejavnost Univerze za tretje življenjsko obdobje). V nadaljnjem besedilu so opredeljene kot»dejavnosti izobraževanja odraslih".

3 3. člen ZIO določa pogoje za opravljanje dejavnosti in opredeljuje: »Organizacije za izobraževanje odraslih, $k i$ izvajajo izobraževalne programe, financirane iz javnih sredstev, morajo izpolnjevati naslednje pogoje:

- da ima strokovni delavec, ki organizira izobraževanje, visokošolsko izobrazbo ustrezne smeri, pedagoškoandragoško izobrazbo in strokovni izpit, predpisan za področje izobraževanja (v nadaljnjem besedilu: strokovni izpit),

- da ima zagotovljene učitelje in druge strokovne delavce, ki izpolnjujejo pogoje, predpisane za posamezna področja izobraževanja, in

- da razpolaga s prostori in opremo, predpisano za izvedbo posameznega izobraževalnega programa.

Smer visokošolske izobrazbe in minimalne standarde prostorov in opreme določi minister, pristojen za izobraževanje odraslih (v nadaljnjem besedilu: minister). $V$ postopku priprave si mora minister pridobiti mnenje pristojnega strokovnega sveta."

4 Pri tem je mišljena univerzitetna raven študija andragogike (v kombinaciji s pedagogiko, drugimi smermi ali samostojno) po starih programih.

5 Sredstva za izobraževanje odraslih načrtuje ministrstvo $z a$ šolstvo in šport (MŠŠ), v deležu tudi v sodelovanju $z$ ministrstvom za delo, družino in socialne zadeve, pri čemer MŠŠ kot pristojno ministrstvo za področje vzgoje in izobraževanje usmerja tudi razvoj strokovnih delavcev na tem področju.

6 Objava: Ur. l. RS št. 70/2004.

7 Evropska komisija je na ravni držav članic od oktobra 2011 (Draft Council Resolution on a renewed European agenda for adult learning Adoption of a Council Resolution, 13. October 2011) usklajevala končni osnutek dokumenta in ga uskladila ter ga predložila v sprejem svetu za izobraževanje, mladino in kulturo 28. novembra 2011. 